\title{
PENGARUH SISTEM PENGENDALIAN KEUANGAN DAERAH DENGAN METODE VALUE FOR MONEY TERHADAP KUALITAS LAPORAN KEUANGAN DAERAH (Studi Kasus Pada BPKAD Kota Bengkulu)
}

\author{
Subaeti $^{1}$, Weni Susanti ${ }^{2}$, Monalisa Sianturi ${ }^{3}$ \\ ${ }^{1,3}$ Fakultas Ekonomi, Universitas Prof. Dr. Hazairin, SH. Bengkulu, \\ ${ }^{2}$ Fakultas Ekonomi, Universitas Tridinanti Palembang \\ E-mail : ${ }^{1}$ subaetiapip@gmail.com, ${ }^{2}$ wenisusanti50@gmail.com, ${ }^{3}$ monalisa.sianturi@gmail.com
}

\begin{abstract}
ABSTRACK
This study aims to determine how much influence the regional financial control system has on the economy, efficiency, effectiveness on the quality of regional financial reports at BPKAD Bengkulu City. The research method uses data quality test, classical assumption test, multiple linear regression analysis, $t$ test, $F$ test, and the coefficient of determination. The results of the calculation obtained a multiple linear regression equation, namely $Y=3.329+0.255 X 1+$ $0.588 X 2+0.111 X 3+e$, from the equation it means that there is a positive influence between the two variables. The coefficient of determination $\left(R^{2}\right)$ of 0.863 and Adjusted $R$ Square of 0.852 indicate that the influence of the regional financial control system on the economy, efficiency, effectiveness on the quality of regional financial reports is very strong. Based on the $t$ value obtained in the hypothesis test (t-test), it was obtained X1 with a tcount of 2.379 with a significant value of 0.023, for X2 for tcount of 5.461 with a significant value of 0.000 , and for X3 for tcount of 2.332 with a significant value of 0.025 , while the t-table value of 1.68830 (tcount>ttable). The hypothesis is accepted or a significant value <0.05. Based on the F value obtained in the hypothesis test (F-test), the Fcount is 75.644> Ftable is 2.87. The hypothesis is accepted or a significant value $<0.05$. This means that the regional financial control system with economy, efficiency, effectiveness has a significant positive effect on the quality of regional financial reports at BPKAD Bengkulu.
\end{abstract}

Keywords : Regional Financial Accounting Systems, Quality of Regional Financial Reports

\begin{abstract}
ABSTRAK
Penelitian ini bertujuan untuk mengetahui seberapa besar pengaruh sistem pengendalian keuangan daerah dengan ekonomi, efisiensi, efektivitas terhadap kualitas laporan keuangan daerah di BPKAD Kota Bengkulu. Metode penelitian menggunakan uji kualitas data, uji asumsi klasik, analisis regresi linear berganda, uji t, uji F, dan koefisien determinasi. Hasil Perhitungan diperoleh persamaan regresi linear berganda yaitu $\mathrm{Y}=3,329+0,255 \mathrm{X} 1+0,588 \mathrm{X} 2+0,111 \mathrm{X} 3+\mathrm{e}$, dari persamaan diartikan bahwa terdapat pengaruh positif antara kedua variabel tersebut. Nilai koefisien determinasi $\left(\mathrm{R}^{2}\right)$ sebesar 0,863 dan Adjusted $\mathrm{R}$ Square sebesar 0,852 menunjukkan pengaruh sistem pengendalian keuangan daerah dengan ekonomi, efisiensi, efektivitas terhadap kualitas laporan keuangan daerah sangat kuat. Berdasarkan nilai t yang diperoleh dalam uji hipotesis (uji-t), diperoleh $\mathrm{X}_{1}$ dengan nilai $\mathrm{t}_{\text {hitung }}$ sebesar 2,379 dengan nilai signifikan 0,023, untuk $t_{\text {hitung }} X_{2}$ sebesar 5,461 dengan nilai signifikan 0,000, dan $t_{\text {hitung }} X_{3}$ sebesar 2,332 dengan nilai signifikan 0,025 , sedangkan nilai $t_{\text {tabel }}$ sebesar 1,68830 ( $t_{\text {hitung }}>t_{\text {tabel }}$ ). Hipotesis diterima atau nilai signifikan $<0,05$. Berdasarkan nilai $\mathrm{F}$ yang diperoleh dalam uji hipotesis (uji-F), diperoleh $\mathrm{F}_{\text {hitung }}$ sebesar 75,644 $>F_{\text {tabel }}$ sebesar 2,87. Hipotesis diterima atau nilai signifikan $<0,05$. Artinya sistem pengendalian keuangan daerah dengan ekonomi, efisiensi, efektivitas berpengaruh positif signifikan terhadap kualitas laporan keuangan daerah di BPKAD Bengkulu.
\end{abstract}

Kata Kunci : Sistem Akuntansi Keuangan Daerah, Kualitas Laporan Keuangan Daerah 


\section{PENDAHULUAN}

Mencapai cita-cita bangsa dan bernegara, perlu adanya sistem yang bertanggungjawab agar setiap suara rakyat dan pembangunan bangsa bebas dari KKN, ini merupakan syarat yang harus ada pada pemerintah agar terciptanya good governance (Sedamayanti, 2004:10). Hal ini sejalan dengan tujuan good governance bahwa pemerintahan yang baik adalah yang mampu menciptakan pemerintahan yang kukuh, berdayaguna dan berhasil serta bermanfaat bagi masyarakatnya (Kurniawan, 2005:10).

Seiring dengan berjalannya waktu, keuangan daerah telah banyak mengalami perubahan. Guna terciptanya transparansi dan akuntabilitas dalam pengelolaan keuangan pemerintah daerah yang baik, maka penyajian laporan keuangan harus sudah mengikuti prosedur dan peraturan yang ada, supaya menghasilkan laporan keuangan pemerintah daerah yang berkualitas. Laporan keuangan dikatakan berkualitas, apabila telah sesuai dengan standar yang ditetapkan, pengungkapan yang cukup dan patuh terhadap peraturan undangundang dan sistem internal yang memadai. Penyajian laporan keuangan akan diperiksa oleh auditor eksternal yaitu Badan Pemeriksa Keuangan (BPK) untuk menilai tingkat kewajaran dalam laporan keuangaan tersebut.

Berdasarkan hasil audit temuan Badan Pemeriksa Keuangan (BPK) pada tahun 2016 dan 2017 memberikan pendapat Wajar Dengan Pengecualian (WDP) terhadap laporan keuangan Pemerintah Kota Bengkulu, hal ini dikarenakan sistem pengendalian internal memadai, namun terdapat kesalahan penyajian pada beberapa pos laporan keuangan. Dalam mengambil keputusan agar tidak terjadi kekeliruan, pemerintah harus memperhatikan beberapa kesalahan yang didalam laporan keuangan tersebut. Sedangkan pada tahun 2018 Pemerintah Kota Bengkulu mendapat pendapat Wajar Tanpa Pengecualian (WTP), hal ini dikarenakan sistem pengendalian internal memadai dan tidak terdapat kesalahan penyajian pada laporan keuangan, serta secara keseluruhan laporan keuangan telah mengikuti standar dan perundangundangan yang telah ditetapkan.

Menurut Peraturan Pemerintah Nomor 71 Tahun 2010 Tentang Standar Akuntansi Pemerintah, penyajian laporan keuangan pemerintah dikatakan berkualitas apabila telah memenuhi kriteria yaitu relevan, andal, dapat dipahami, dan dapat dibandingkan. Salah satu cara yang dapat dipertimbangkan untuk mengetahui kualitas laporan keuangan pemerintah daerah adalah dengan melihat pengaruh sistem pengedalian keuangan daerah melalui metode value for money. Didalam pengurusan organisasi sektor publik, terdapat tiga elemen penting yang disebut Value for money yaitu Ekonomi, Efisiensi, dan Efektivitas (Mardiasmo, 2009:4).

Mardiasmo (2009:4) menyatakan bahwa ekonomi adalah pemerolehan input dengan kualitas dan kuantitas tertentu pada harga terendah. Ekonomi terkait dengan bagaimana upaya organisasi sektor publik dapat memperkecil sumber daya masukkan untuk menghindari pengeluaran yang boros dan tidak produktif. Efisiensi merupakan perbandingan antara pengeluaran yang dihasilkan terhadap pemasukkan yang digunakan. Dikatakan efisiensi jika suatu hasil kerja dapat dicapai dengan dana yang serendah-rendahnya. Efektivitas merupakan tingkat pencapaian hasil program dengan target yang ditetapkan.

\section{TINJAUAN PUSTAKA}

\subsection{Akuntansi Keuangan}

Menurut Syofian Syafri Harapan (2008:5), akuntansi adalah seni pencatatan, penggolongan, dan pengikthisaran dengan cara tertentu dan dalam ukuran moneter, transaksi, dan kejadian-kejadian yang umumnya bersifat keuangan dan termasuk 
menafsirkan hasil-hasilnya. Akuntansi keuangan merupakan suatu bidang akuntansi yang berorientasi pada pihak eksternal dan internal dengan tujuan spesifik bagi masingmasing pihak. Dalam laporan akuntansi menghasilkan informasi keuangan tentang sebuah entitas.

Laporan keuangan merupakan bagian dari proses pelaporan keuangan. Laporan keuangan yang disajikan tersebut hendaknya dapat memenuhi kebutuhan pemakai informasi keuangan yaitu dapat memberi informasi secara kuantitatif, lengkap, dan dapat dipercaya. Laporan keuangan disusun untuk memenuhi kebutuhan bersama sebagian besar pemakai. Penyusunan laporan keuangan yang berpedoman pada Standar Akuntansi Pemerintah sesungguhnya adalah dalam rangka peningkatan kualitas laporan keuangan, agar terwujudnya good government governance.

\subsection{Good Government Governance}

Menurut Ganie Rochman, konsep government menunjuk pada suatu organisasi pengelolaan berdasarkan wewenang tertinggi (negara dan pemerintah), sedangkan menurut Lembaga Administrasi Negara (LAN) dinyatakan bahwa governance adalah proses penyelenggaraan kekuasaan negara dalam melaksanakan penyediaan public god and service atau bisa juga disebut good governance.

Menurut J.S Endarlin bahwa governance merupakan suatu terminologi yang digunakan untuk menggantikan istilah government, yang menunjukkan penggunaan otoritas politik, ekonomi, dan administrasi dalam mengelola masalah-masalah kenegaraan. Istilah ini secara khusus menggambarkan perubahan peranan pemerintah dari pemberi pelayanan kepada enabler atau fasilitator, dan perubahan kepemilikan yaitu dari milik negara menjadi milik rakyat (Dharma, 2002:223).

\subsection{Prinsip Good Government Governance}

Prinsip good governance adalah untuk memberikan mekanisme dan pedoman dalam memberikan keseimbangan bagi para stakeholders dalam memenuhi kepentingannya masing-masing. Menurut UNDP (United Nations Development Programs, 1997), prinsip-prinsip Good Governance terdapat 9 (Sembilan) prinsip untuk melaksanakan praktik tata pemerintahan yang baik, meliputi :

1. Parsipasi Masyarakat. Setiap warga masyarakat, baik laki-laki maupun perempuan harus memiliki hak suara yang sama dalam proses pengambilan keputusan, baik secara langsung atau melalui perwakilan sesuai dengan kepentingan dan aspirasinya masingmasing.

2. Aturan Hukum (Rule of Law). Kerangka aturan hokum dan perundang-undangan haruslah berkeadilan, ditegakkan dan dipatuhi secara utuh.

3. Transparasi. Transparansi harus dibangun dalam kerangka kebebasan aliran informasi. Berbagai proses, kelembagaan, dan informasi harus dapat diakses secara bebas oleh orang yang membutuhkan.

4. Daya Tangkap. Setiap institusi harus diarahkan pada upaya untuk melayani berbagai pihak yang berkepentingan.

5. Berorientasi Konsesus. Pemerintah yang harus bertindak sebagai penengah bagi berbagai kepentingan yang berbeda untuk mencapai kesepakatan yang terbaik bagi kepentingan masing-masing pihak dan dimungkinkan dapat diberlakukan terhadap berbagai kebijakan yang ditetapkan pemerintah.

6. Berkeadilan. Pemerintah yang baik harus memberikan kesempatan yang sama baik laki-laki maupun perempuan dalam upaya mereka meningkatkan dan memelihara kualitas hidupnya.

7. Efektivitas dan Efisiensi. Setiap proses kegiatan dan kelembagaan diarahkan 
untuk menghasilkan pemanfaatan yang sebaik-baiknya berbagai sumber-sumber yang tersedia.

8. Akuntabilitas. Para pengambil keputusan dalam organisasi sektor publik, swasta atau masyarakat memiliki pertanggung jawaban kepada publik.

9. Visi Strategi. Para pemimpin dan masyarakat harus memiliki perspektif yang luas dan jangka panjang tentang penyelenggaraan pemerintah yang baik dan membangun manusia, bersama dengan dirasakannya kebutuhan untuk pembangunan tersebut.

\subsection{Laporan Keuangan Daerah}

Laporan keuangan merupakan bagian dari proses pelaporan keuangan. Laporan keuangan yang disajikan tersebut hendaknya dapat memenuhi kebutuhan pemakai informasi keuangan yaitu dapat memberi informasi secara kuantitaf, lengkap, dan dapat dipercaya. Disamping itu laporan keuangan harus mencerminkan keadaan secara tepat dan netral sehingga para pengambil keputusan yang mendasarkan diri pada laporan keuangan tidak tersesat.

PSAP Nomor 01 Tahun 2010 berlaku untuk entitas pelaporan dalam menyusun laporan keuangan suatu enstitas pemeritah pusat, pemerintah daerah, dan laporan keuangan konsolidasi, tidak termasuk perusaahaan negara atau daerah. Entitas pelaporan menyelenggarakan akuntansi dan penyajian laporan keuangan dengan menggunakan basis akrual baik dalam pengakuan pendatan dan beban, maupun pengakuan asset, kewajiban, dan ekuitas. Entitas pelaporan yang menyelenggarakan akuntansi berbasis akrual, menyajikan Laporan Realisasi Anggaran berdasarkan basis yang ditetapkan dalam peraturan perundang-undangan tentang anggaran. Komponen-komponen yang terdapat dalam satu set laporan keuangan terdiri dari laporan pelaksanaan anggaran (budgetary repots) dan laporan financial, sehinnga seluruh komponen menjadi sebagai berikut :

1. Laporan Realisasi Anggaran;

2. Laporan Perubahan Saldo Anggaran Lebih;

3. Neraca;

4. Laporan Operasional;

5. Laporan Arus Kas;

6. Laporan Perubahan Ekuitas;

7. Catatan atas Laporan Keuangan.

Komponen-komponen laporan keuangan tersebut disajikan oleh setiap entitas pelaporan, kecuali :

1. Laporan Arus Kas yang hanya disajikan oleh entitas yang mempunyai perbendaharaan umum;

2. Laporan Perubahan Saldo Anggaran Lebih yang hanya disajikan oleh Bendahara Umum Negara dan entitas pelaporan yang menyusun laporan keuangan konsolidasiannya.

Unit yang mempunyai fungsi perbendahara umum adalah unit yang ditetapkan sebagai bendahara umum negara atau daerah dan atau sebegai kuasa bendahara umum negara atau daerah. Kegiatan keuangan pemerintah dibatasi dengan anggaran dalam bentuk apropriasi atau otoritas anggaran. Laporan keuangan menyediakan informasi mengenai apakah sumber daya ekonomi telah diperoleh dan digunakan sesuai dengan anggaran yang telah ditetapkan. Laporan Realisasi Anggaran memuat anggaran dan realisasi. Entitas pelaporan pemerintah pusat juga menyajikan Saldo Anggaran Lebih pemerintah yang mencakup Saldo Anggaran Lebih tahun sebelumnya, penggunaan Saldo Anggaran Lebih, Sisa Lebih/Kurang Pembiayaan Anggaran (SiLPA/SiKPA) tahun berjalan, dan penyesuaian lain yang diperkenankan.

Laporan keuangan memberikan informasi tentang sumber daya ekonomi dan kewajiban entitas pelaporan pada tanggal pelaporan dan arus sumber daya ekonomi 
selama periode berjalan. Informasi ini diperlukan pengguna untuk melakukan penilaian terhadap kemampuan entitas pelaporan dalam menyelenggarakan kegiatan pemerintahan dimasa mendatang. Entitas pelaporan menyajikan informasi untuk membantu para pengguna dalam memperkirakan hasil operasi entitas dan pengelolaan aset, seperti halnya dalam pembuatan dan evaluasi keputusan mengenai alokasi sumber daya ekonomi.

Entitas yang mempunyai fungsi perbendaharaan umum menyajikan informasi mengenai sumber, penggunaan, perubahan kas dan setara kas selama suatu periode akuntansi dan saldo kas dan setara kas pada tanggal pelaporan. Entitas pelaporan menyajikan kekayaan bersih pemerintah yang mencakup ekuitas awal, surplus/defisit period bersangkutan, dan dampak kumulatif akibat perubahan kebijakan dan kesalahan mendasar. Untuk menghindari kesalahpahaman dalam membaca laporan keuangan, entitas pelaporan harus mengungkapkan semua informasi penting baik yang telah tersaji maupun yang tidak tersaji dalam lembar muka laporan keuangan. Entitas pelaporan mengungkapkan informasi tentang ketataan terhadap anggaran.

Menurut Peraturan Pemerintah Republik Indonesia Pasal 1 Nomor 58 Tahun 2005 tentang Pengelolaan Keuangan Daerah, keuangan daerah adalah semua hak dan kewajiban daerah dalam rangka penyelenggaraan Pemerintah Daerah yang dapat dinilai dengan uang termasuk didalamnya segala bentuk kekayaan yang berhungan dengan hak dan kewajiban daerah tersebut dan tentunya batas-batas kewenangan daerah. Pemerintah Daerah dengan segala aspek keuangan yang terdapat didalamnya akan dapat dijalankan jika baik sesuai dengan Peraturan Menteri Dalam Negeri Nomor 13 Tahun 2006 tentang Pedoman Pengelolaan Keuangan Daerah, yang menjelaskan bahwa pengelolaan keuangan daerah adalah keseluruhan kegiatan yang meliputi perencanaan, pelaksanaan, penatausahaan, pelaporan, pertanggungjawaban, dan pengawasan keuangan daerah.

Keuangan daerah dijelaskan dalam UU Nomor 32 Tahun 2004 tentang Pemerintah Daerah yaitu penyelenggara urusan pemerintah yang menjadi kewenangan daerah di danai dari dan atas beban pendapatan belanja daerah. Menurut Peraturan Menteri Dalam Negeri Nomor 13 Tahun 2006, struktur APBD merupakan suatu kesatuan yang terdiri dari:

1. Pendapatan Daerah;

2. Belanja Daerah, dan

3. Pembiayaan Daerah.

Keuangan daerah dikelola secara tertib, taat pada peraturan perundangundangan, efektif, efisien, ekonomis, transparan, dan bertanggung jawab dengan memperhatikan azas keadilan, kepatuhan, dan mafaat untuk masyarakat.

\subsection{Sistem Pengendalian Keuangan Daerah \\ Organisasi pemerintah daerah} memerlukan sistem pengendalian manajemen untuk memberikan jaminan dilaksanakannya strategi organisasi secara efektif dan efisien sehinggga tujuan organisasi dapat dicapai. Kegagalan organisasi dalam mencapai tujuan yang telah ditetapkan karena adanya kelemahan atau kegagalan pada salah satu atau beberapa tahap dalam proses pengendalian manajemen. Sistem pengendalian keuangan pemerintah daerah yang melaksanakan strategi organisasi secara efektif dan efisien sehingga tujuan organisasi dapat dicapai.

Penerimaan dan pengerluaran daerah (APBD) harus selalu dimonitor, yaitu dibandingkan antara dianggarkan dengan yang ingin dicapai. Menurut Mardiasmo (2002:171), manajemen keuangan daerah didasari oleh prinsip-prinsip yang harus senantiasa dipegang teguh serta dilaksanakan 
oleh penyelenggara pemerintah, karena pada dasarnya masyarakat (publik) memiliki hak dasar terhadap pemerintah, yaitu :

1. Hak untuk mengetahui (right to know), yaitu mengetahui kebijakan pemerintah, mengetahui keputusan yang diambil pemerintah, dan mengetahui alasan dilakukannya suatu kebijakan dan keputusan tertentu.

2. Hak untuk diberi informasi (right to be informed), yaitu meliputi hak untuk diberi penjelasan secara terbuka atas permasalahan-permasalahan tertentu yang menjadi perdebatan publik.

3. Hak untuk didengar aspirasinya (right to be heard and to be listened to).

Laporan keuangan pemerintah merupakan hak publik yang harus diberikan oleh pemerintah, baik pusat maupun daerah. Hak publik atas informasi keuangan muncul sebagai konsekuensi konsep pertanggungjawaban publik. Pertanggungjawaban publik masyarakat organisasi publik untuk memberikan laporan keuangan sebagai bukti pertanggungjawaban dan pengelolaan (accountability and stewardship).

Penerbitan Pedoman Standar Akuntansi Pemerintah (PSAP) merupakan awal masing-masing pihak untuk bersamasama mewujudkan good governance melalui penerapan Standar Akuntansi Pemerintah (SAP) dalam penyusunan laporan pertanggungjawaban pelaksanaan APBN/APBD oleh semua instansi pemerintah pengguna anggaran baik di pusat maupun di daerah. Selama ini terdapat beberapa aturan yang digunakan sebagai rujukan pemerintah daerah dalam penyusunan laporan keuangan.

\subsection{Value for Money}

Value for money menurut Mardiasmo (2009:4), merupakan konsep pengelolaan organisasi sektor publik yang mendasarkan pada tiga elemen utama, yaitu ekonomis, efisiensi, dan efektivitas.
Pemerintah daerah dituntut semaksimal mngkin dalam membelanjakan anggaran sehingga tidak terjadi defisit anggaran yang ditetapkan, serta mendahulukan kegiatan prioritas dan mengacu pada peraturan yang berlaku sehingga ekonomis, efisien dan efektif bisa tercapai. Beberapa hal memang sulit untuk diukur, tidak berwujud dan bersifat subyektif sehingga sering disalah artikan, karena itu dibutuhkan persiapan yang maksimal dalam menentukan apakah prinsip Value for Money telah diterapkan dan dicapai dengan baik. Value for money tidak semata mengukur biaya barang dan jasa melainkan juga memasukkan gabungan dari unsur kualitas biaya, sumber daya yang digunakan ketetapan penggunaan, batasan waktu dan kemudahan dalam menilai apakah secara bersamaan kesemua unsur tersebut membentuk "value" (nilai) yang baik. Kerangka pengukuran value for money dibangun atas tiga kompenen utama, yaitu :

1. Kompenen visi, misi, tujuan, sasaran dan target;

2. Kompenen input, output, dan outcome;

3. Kompenen pengukuran ekonomi, efisiensi, dan efektivitas.

Implementasi konsep value for money pada organisasi sektor publik perlu gencar dilakukan seiring dengan meningkatnya tuntutan akuntabilitas publik dan pelaksanaan good governance. Implementasi konsep tersebut diyakini dapat memperbaiki kineja sektor publik dengan meningkatkan efektivitas layanan publik, meningkatkan mutu layanan publik, menurunkan biaya layanan publik karena hilangnya efisiensi dan meningkatkan kesadaran akan pengguna uang publik (public costs awareness).

Value for money menurut Mardiasmo (2009:18), merupakan konsep pada tiga elemen utama yaitu ekonomis, efisiensi, dan efektivitas. Value for money merupakan jembatan pemerintah untuk mencapai good governance. 
1. Ekonomi

Ekonomi adalah pemerolehan input dengan kualitas dan kuantitas tertentu pada harga yang terendah. Dengan kata lain, ekonomi adalah praktik pembelian barang dan jasa input dengan tingkat kualitas tertentu pada harga terbaik yang di mungkinkan. Dalam konteks organisasi pemerintahan, ukuran ekonomi berupa berapa anggaran yang dialokasikan untuk membiayai aktivitas tertentu.

Mahmudi (2010:84), menyatakan bahwa ekonomi memiliki perhitungan membandingkan input dengan input value sebagai berikut :

$$
\text { Ekonomis }=\frac{\text { Input } \quad X}{\text { Harga input }} 100 \%
$$

Menurut Mahsum (2006:186), dikatakan ekonomi apabila memiliki beberapa kriteria sebagai berikut :

a. Jika diperoleh nilai kurang dari $100 \%$, maka tidak ekonomis.

b. Jika diperoleh nilai sama dengan $100 \%$, maka ekonomi seimbang.

c. Jika diperoleh nilai lebih dari $100 \%$, maka tidak ekonomi.

\section{Efisiensi}

Menurut Mardiasmo (2009:18), efisiensi merupakan pencapaian output yang maksimum dengan input tertentu untuk penggunaan yang terendah untuk pencapaian tertentu. Efisiensi mengkur biaya atas output (cost of output), seberapa baik organisasi mampu memanfaatkan sumber daya yang dimilikinya untuk menghasilkan output. Dalam pengukuran value for money, efiensi dapat dibagi menjadi dua, yaitu :

a. Efisiensi alokasi, terkait dengan kemampuan untuk menyalahgunakan sumber daya input pada tingkat kapasitas optimal.

b. Efisiensi teknis atau manajerial, terkait dengan kemampuan mendayagunakan sumber daya input pada tingkat output tertentu.

Menurut Mahmudi (2010:85), tingkat efisiensi dapat diketahui dengan perhitungan sebagai berikut :

Efisiensi $=\frac{\text { Output }}{\text { Input }} \times 100 \%$

Mahsun (2006:187) menyatakan bahwa efisiensi memiliki kriteria, yaitu sebagai berikut:

a. Jika nilai kurang dari $100 \%$, maka dikatakan tidak efisiens.

b. Jika diperoleh nilai sama dengan $100 \%$, maka dikatakan efisiens berimbang.

c. Jika didapat nilai lebih dari $100 \%$, maka dikatakan efisien

\section{Efektivitas}

Efektivitas adalah ukuran berhasil tidaknya suatu organisasi mencapai tujuannya. Apabila suatu organisasi berhasil mencapai tujuan, maka organisasi tersebut telah berjalan dengan efektif. Efektivitas hanya melihat apakah suatu program atau kegiatan telah mencapai kegiatan yang telah ditetapkan. Pengukuran efektivitas mengukur hasil akhir dari suatu pelayanan dikaitkan dengan outputnya (cost of outcome).

Indikator

efektivitas menggambarkan jangkauan akibat dan dampak (outcome) dari keluaran (output) program dalam mencapai tujuan program. Semakin kontribusi output yang dihasilkan berperan terhadap pencapaian tujuan atau sasaran yang ditentukan, maka semakin efektivitas proses kerja suatu unit organisasi. Pengukuran efektivitas bisa dilakukan hanya dengan mengukur outcome. Suatu layanan mungkin dilakukan secara efisien, namun belum tentu efektif jika pelayanan tersebut tidak menambah nilai bagi pelanggan. Oleh karena itu, indikator efisiensi dan efektivitas harus digunakan secara bersama-sama. Jika suatu program dinyatakan efektif dan efisien, maka program tersebut dapat dikatakan cost- 
effectiviness.

Dalam pengukuran efektivitas, terdapat perhitungan tingkat efektivitas menurut Mahmudi (2010:187) sebagai berikut :

\section{Efektivitas $=\underline{\text { Outcome }} \quad \mathrm{X} 100 \%$ Output}

Menurut Mahsun (2006: 187), efektivitas juga memiliki beberapa kriteria, sebagai berikut :

1. Jika didapat nilai kurang dari $100 \%$, maka dikatakan tidak efektif.

2. Jika didapat nilai sama dengan $100 \%$, maka dikatakan efektif berimbang.

3. Jika didapat nilai lebih dari $100 \%$, maka dikatakan efektif.

Dari uraian diatas, jelaslah bahwa ketiga pokok bahasan dalam value for money sangat terikat satu dengan yang lainnya. Ekonomi membahas mengenai pemerolehan input dengan kualitas dan kuantitas tertentu pada harga yang terendah, efisiensi membahas mengenai output yang dihasilkan apakah telah mencapai input yang telah ditargetkan, dan efektivitas membahas mengenai tujuan output berhasil atau tidaknya.

\subsection{Kualitas Laporan Keuangan Daerah}

Menurut Peraturan Pemerintah Nomor 71 Tahun 2010, pengertian laporan keuangan merupakan laporan yang terstruktur mengenai posisi keuangan dan transaksi-tranksaksi yang dilakukan oleh suatu entitas pelaporan.

Menurut Bastian (2010:297), laporan keuangan sektor publik adalah representasi posisi keuangan dari transaksi-transaksi yang dilakukan oleh suatu entitas sektor publik. Entitas pelaporan menurut Peraturan Pemerintah Nomor 71 Tahun 2010 merupakan unit pemerintah yang terdiri dari satu atau lebih entitas akuntansi yang menurut ketentuan wajib menyampaikan laporan pertanggungjawaban berupa laporan keuangan yang terdiri dari pemerintah pusat, pemerintah daerah, dan organisasi di lingkungan pemerintah pusat dan daerah yang jika menurut peraturan perundangundangan wajib menyampaikan laporan keuangan.

\subsection{Karakteristik Kualitas Laporan Keuangan Daerah \\ Berdasarkan Peraturan Menteri} Dalam Negeri Republik Indonesia Nomor 64 Tahun 2013 tentang Penerapan Standar Akuntansi Pemerintahan berbasis akrual pada Pemerintah Daerah adalah prinsipprinsip akuntansi yang diterapkan dalam menyusun dan menyajikan laporan keuangan Pemerintah. Menurut Peraturan Pemerintah Nomor 71 Tahun 2001 Tentang Standar Akuntansi Pemerintahan (SAP) adalah ukuran-ukuran normatif yang perlu diwujudkan dalam informasi akuntansi sehingga dapat memenuhi tujuannya. Ada empat karakteristik yang diperlukan merupakan prasyarat normatif agar keuangan Pemerintah dapat memenuhi kualitas yang baik, yaitu sebagai berikut :

a. Relevan. Apabila informasi yang termuat didalam laporan keuangan dapat mempengaruhi keputasan pengguna dengan membantu mereka mengevaluasi peristiwa masa lalu ataupun masa kini juga memprediksi masa depan, maka laporan keuangan tersebut bisa dikatakan relevan. Dikatakan relevan juga harus memberikan informasi agar dapat dihubungkan dengan maksud penggunanya, yaitu sebagai berikut:

1) Memiliki manfaat umpan balik (feedback value), informsasi tersebut memungkinkan penggunananya untuk menegaskan ataupun mengoreksi ekspektasi mereka di masa lalu.

2) Memiliki manfaat prediktif (predictive value), informasi tersebut dapat membantu pengguna 
untuk memprediksi masa yang akan datang dilihat dari hasil masa lalu dan kejadian masa kini.

3) Tepat waktu, informasi tersebut menyajikan laporannya teppat waktu yang dapat berpengaruh dan berguna dalam mengambil keputusan.

4) Lengkap, informasi akuntansi keuangan pemerintah disajikan selengkap-lengkapnya dan mencakup semua informasi akuntansi yang dapat mempengaruhi pengambilan keputusan dengan mempengaruhi kendala yang ada. Informasi tersbut melatar belakangai setiap butir informasi utama yang termuat dalam laporan keuangan diungkapkan dengan jelas agar kekeliruan dalam penggunaan informasi tersebut dapat dicegah.

b. Andal. Informasi dalam laporan keuangan bebas dari pengertian yang menyesatkan dan kesalahan material, menyajikan setiap fakta secara jujur, serta dapat diverifikasi. Informasi mungkin relevan tetapi jika hakikat atau penyajiannya tidak dapat diandalkan maka penggunaan informasi tersbut secara potensial dapat menyesatkan. Berikut karakteristik informasi yang andal, yaitu :

1) Penyajian jujur, informasi menggambarkan dengan jujur transaksi serta peristiwa lainnya yang seharusnya disajikan atau yang secara wajar dapat diharapkan untuk disajikan.

2) Dapat Diverifikasi (verifiability), informasi yang disajikan dalam laporan keuangan dapat diuji dan apabila pengujian dilakukan lebih dari sekali oleh pihak yang berbea, hasilnya tetap menunjukkan simpulan yang tidak berbeda jauh.
3) Netralitas, informasi diarahkan pada kebutuhan umum dan tidak berpihak pada kebutuhan pihak tertentu.

c. Dapat Dibandingkan. Penyajian informasi dalam laporan keuangan dapat dipahami oleh pengguna dan dinyatakan dalam bentuk serta istilah yang disesuaikan dengan batas pemahaman para pengguna. Untuk itu, pengguna diasumsikan memiliki pengetahuan yang memadai atas kegiatan dan lingkungan operasi entitas pelaporan, serta adanya kemauan pengguna untuk memperlajari informasi yang dimaksudkan dalam laporan keuangan.

Dalam memberikan manfaat laporan keuangan bagi para pemakainnya, maka laporan keuangan tersebut harus mempunyai nilai informasi yang berkualitas dan berguna dalam pengambilan keputusan. Laporan keuangan yang berkualitas menunjukkan bahwa kepala daerah bertanggungjawab dengan wewenang yang dilimpahkan kepadanya dalam pelaksanaan tanggung jawab mengeloa organisasi. Penyajian informasi dalam laporan keuangan yang digunakan dalam pengambilan keputusan ekonomi, sosial dan politik serta berbagai bukti pertanggungjawaban dan pengelolaan untuk mengevaluasi kinerja organisasi serta kesesuaian dengan peraturan perundangundangan yang menjadi pedoman dalam pembuatan laporan keuangan.

\subsection{Hipotesis}

Menurut Sugiyono (2005:96), hipotesis adalah jawaban sementara terhadap rumusan masalah. Berdasarkan teori dan kerangka pemikiran yang telah diungkapkan di atas, maka hipotesis penelitian ini adalah :

$\mathbf{H}_{1}$ : Diduga ada pengaruh positif signifikan sistem pengendalian keuangan daerah dengan ekonomi terhadap kualitas laporan keuangan BPKAD Kota 
Bengkulu.

$\mathbf{H}_{2}$ : Diduga ada pengaruh positif signifikan sistem pengendalian keuangan daerah dengan efisiensi terhadap kualitas laporan keuangan BPKAD Kota Bengkulu.

$\mathbf{H}_{3}$ : Diduga ada pengaruh positif signifikan sistem pengendalian keuangan daerah dengan efektifitas terhadap kualitas laporan keuangan BPKAD Kota Bengkulu.

$\mathbf{H}_{4}$ : Diduga secara simultan ada pengaruh positif signifikan ekonomi, efisiensi, dan efektifitas terhadap kualitas laporan keuangan BPKAD Kota Bengkulu.

\section{METODOLOGI PENELITIAN}

\subsection{Populasi}

Populasi pada penelitian ini adalah pegawai yang bekerja di Badan Pengelolaan Keuangan dan Aset Daerah (BPKAD) Kota Bengkulu sebanyak 60 orang.

\subsection{Sampel}

Sampel dalam penelitian ini karyawan yang berada di BPKAD Kota Bengkulu yaitu sebanyak 40 orang pada bidang anggaran, bidang akuntansi dan perbendaharaan, dan bidang aset. Teknik pengambilan sampel dalam penelitian ini adalah purposive sampling. Purposive sampling yaitu tekni pengambilan sampel sumber data dengan pertimbangan tertentu. Adapun criteria yang digunakan dalam pengambilan sampel sebagai berikut :

1. Pegawai yang kompeten dalam bidangnya.

2. Pegawai tetap pada Badan Pengelolaan Keuangan dan Aset Daerah (BPKAD) Kota Bengkulu.

3. Bidang yang langsung menangani keuangan dan laporan keuangan.

\subsection{Teknik Pengambilan Sampel}

Teknik pengumpulan data yang digunakan dalam penlitian ini adalah sebagai berikut:

1. Observasi

2. Kuesioner

3. Studi Pustaka

4. Data Keuangan Daerah

Data keuangan yang dimaksud adalah Opini Atas Laporan keuangan Badan Pengelolaan Keuangan dan Aset Daerah (BPKAD) di Kota Bengkulu yang dari tahun 2016 sampai dengan 2018 yang telah di audit.

\section{HASIL DAN PEMBAHASAN}

4.1 Hasil Penelitian

1. Hasil Uji Regresi Linear Berganda

Tabel 1

Hasil Uji Regresi Linear Berganda

Coefficients $^{\mathrm{a}}$

\begin{tabular}{|c|c|c|c|c|c|c|}
\hline \multirow{2}{*}{\multicolumn{2}{|c|}{ Model }} & \multicolumn{2}{|c|}{$\begin{array}{l}\text { Unstandardized } \\
\text { Coefficients }\end{array}$} & \multirow{2}{*}{$\begin{array}{l}\text { Standardized } \\
\text { Coefficients } \\
\text { Beta } \\
\end{array}$} & \multirow[b]{2}{*}{$\mathrm{t}$} & \multirow[b]{2}{*}{ Sig. } \\
\hline & & $\mathrm{B}$ & $\begin{array}{l}\text { Std. } \\
\text { Error }\end{array}$ & & & \\
\hline \multirow[t]{4}{*}{1} & (Constat) & 3,329 & 2,428 & & 1,372 & 0,179 \\
\hline & Ekonomi (X1) & 0,255 & 0,107 & 0,283 & 2,379 & 0,023 \\
\hline & Efisiensi (X2) & 0,588 & 0,102 & 0,638 & 5,461 & 0,000 \\
\hline & Efektivitas (X3) & 0,111 & 0,047 & 0,149 & 2,332 & 0,025 \\
\hline
\end{tabular}

a. Dependent Variabel: Kualitas Laporan Keuangan Daerah (Y)

Sumber: data primer diolah, 2019

Dari tabel diatas, maka didapat rumus sebagai berikut :

$\mathrm{Y}=3,329+0,255 \mathrm{X}_{1}+0,588 \mathrm{X}_{2}+0,111 \mathrm{X}_{3}+$ $\mathrm{e}$

Penjelasan regresi diatas adalah sebagai berikut :

a. Konstanta (a) sebesar 3,329 mempunyai arti bahwa ekonomi, efisiensi, efektifitas sama dengan nol, maka kualitas laporan keuangan daerah akan tetap 3,329. Hal ini berlaku saat dilaksanakan penelitian berarti jika variabel bebas dianggap konstanta, maka besarnya nilai kualitas laporan keuangan daerah 3,329. 
b. $\mathrm{X}_{1}=0,255$ memiliki makna bahwa setiap variabel $X_{1}$ naik satu-satuan, maka variabel beta $(\mathrm{Y})$ akan ikut naik sebesar 0,255.

c. $\mathrm{X}_{2}=0,588$ memiliki makna bahwa setiap variabel $X_{2}$ naik satu-satuan, maka variabel beta (Y) akan ikut naik sebesar 0,588.

d. $\mathrm{X}_{3}=0,111$ memiliki makna bahwa setiap variabel X3 naik satu-satuan, maka variabel beta (Y) akan ikut naik sebesar 0,111 .

\section{Hasil Uji t (Parsial)}

Uji signifikan secara parsial variabel bebas terhadap variabel tak bebas bertujuan untuk mengukur secara terpisah kontribusi yang ditimbulkan dari masing-masing variabel bebas terhadap variabel tak bebas (Syofian, 2013:250). Dengan membandingkan $t_{\text {hitung }}>t_{\text {tabel }}$, tingkat siginifikansi yang digunakan yaitu $<0,05$. Bila probabilitas $<0,05$ maka terdapat pengaruh antara variabel bebas terhadap variabel terikat. Namun, bila nilai signifikan $>0,05$ maka tidak terdapat pengaruh antara variabel bebas dnegan variabel terikat. Uji ini dilakukan dengan menggunakan SPSS dengan hasil sebagai berikut :

\section{Tabel 2}

Hasil Uji t

Cofficients $^{\mathrm{a}}$

\begin{tabular}{|c|c|c|c|c|c|}
\hline \multirow[t]{2}{*}{ Model } & \multicolumn{2}{|c|}{$\begin{array}{c}\text { Unstandardized } \\
\text { Coefficients }\end{array}$} & \multirow{2}{*}{$\begin{array}{c}\begin{array}{c}\text { Standardiz } \\
\text { ed } \\
\text { Coefficient } \\
\mathrm{s}\end{array} \\
\text { Beta }\end{array}$} & \multirow[b]{2}{*}{$\mathrm{t}$} & \multirow[b]{2}{*}{ Sig. } \\
\hline & B & $\begin{array}{l}\text { Std. } \\
\text { Error }\end{array}$ & & & \\
\hline 1 (Constant) & 3,329 & 2,428 & & 1,372 & 179 \\
\hline $\mathrm{X} 1$ & ,255 & , 107 & ,283 & 2,379 & 023 \\
\hline $\mathrm{X} 2$ & ,558 & , 102 & ,638 & 5,461 & ,000 \\
\hline $\mathrm{X} 3$ & , 111 & ,047 & ,149 & 2,332 & 025 \\
\hline
\end{tabular}

a. Dependent Variable: Y

Sumber: data primer diolah, 2019

Pada tabel diatas, dapat kita lihat bahwa nilai koefisien regresi variabel Sistem Pengendalian Keuangan Daerah dengan
Ekonomi $\left(\mathrm{X}_{1}\right)$ adalah sebesar 0,225 , dan variabel Sistem Pengendalian Keuangan Daerah dengan Efisiensi $\left(\mathrm{X}_{2}\right)$ sebesar 0,558, serta variabel Sistem Pengendalian Keuangan Daerah dengan Efektivitas $\left(X_{3}\right)$ sebesar 0,111 yang menunjukkan nilai positif sehingga semakin baik pula Kualitas Laporan Keuangan (Y), untuk mengetahui pengaruh positif signifikan atau tidaknya, dapat dilihat pada hasil pengujian hipotesis sebagai berikut :

\section{a. Pengujian Hipotesis Pertama $\left(\mathbf{H}_{1}\right)$}

Ditemukan bahwa Sistem Pengendalian Keuangan Daerah dengan Ekonomi dengan nilai $t_{\text {hitung }} 2,379>t_{\text {tabel }} 1,68830$ dengan nilai signifikan $0,023<0,05$ sehingga dapat disimpulkan bahwa hasil $\mathrm{H}_{1}$ diterima, yang berarti Sistem Pengendalian Keuangan Daerah dengan Ekonomi $\left(\mathrm{X}_{1}\right)$ berpengaruh positif signifikan terhadap Kualitas Laporan Keuangan Daerah (Y).

b. Pengujian Hipotesis Kedua $\left(\mathbf{H}_{2}\right)$

Ditemukan bahwa Sistem Pengendalian Keuangan dengan Efisiensi dengan nilai $t_{\text {hitung }} 5,461>t_{\text {tabel }} 1,68830$ dengan nilai signifikan $0,000<0,05$ sehingga dapat disimpulkan bahwa hasil $\mathrm{H}_{2}$ diterima, yang berarti Sistem Pengendalian Keuangan Daerah dengan Efisiensi $\left(\mathrm{X}_{2}\right)$ berpengaruh positif signifikan terhadap Kualitas Laporan Keuangan Daerah (Y).

c. Pengujian Hipotesis Ketiga $\left(\mathbf{H}_{3}\right)$

Ditemukan bahwa Sistem Pengendalian Keuangan dengan Efektivitas dengan nilai $t_{\text {hitung }} 2,332>t_{\text {tabel }} 1,68830$ dengan nilai signifikan $0,025<0,05$ sehingga dapat disimpulkan bahwa hasil $\mathrm{H}_{3}$ diterima, yang berarti Sistem Pengendalian Keuangan Daerah dengan Efektivitas $\left(\mathrm{X}_{3}\right)$ berpengaruh positif signifikan terhadap Kualitas Laporan Keuangan Daerah (Y).

\section{Hasil Uji F (Simultan)}

Uji signifikan secara simultan adalah untuk mengetahui seberapa besar pengaruh 
variabel bebas secara bersama-sama terhadap variabel tak bebas dengan nilai $\mathrm{F}_{\text {hitung }}>\mathrm{F}_{\text {tabel }}$ dan tingkat signifikan $<0,05$ yang berarti terdapat pengaruh positif signifikan secara simultan antara variabel bebas terhadap variabel tak bebas. Untuk menghitung uji $\mathrm{F}$ digunakan SPSS dengan hasil sebagai berikut :

\section{Tabel 3 \\ Hasil Uji F \\ ANOVA $^{\mathrm{a}}$}

\begin{tabular}{|l|r|r|r|c|c|}
\hline Model & \multicolumn{1}{|c|}{$\begin{array}{c}\text { Sum of } \\
\text { Squares }\end{array}$} & Df & $\begin{array}{c}\text { Mean } \\
\text { Square }\end{array}$ & F & Sig. \\
\hline Regression & 348,254 & 3 & 116,085 & 75,644 &, $000^{\mathrm{b}}$ \\
1 Residual & 55,246 & 36 & 1,535 & & \\
Total & 403,500 & 39 & & & \\
\hline
\end{tabular}

a. Dependent Variable: Y

b. Predictors: (Constant), X3, X2, X1

Sumber: data primer diolah, 2019

\section{d. Pengujian Hipotesis Keempat $\left(\mathrm{H}_{4}\right)$}

Berdasarkan tabel diatas, ditemukan bahwa nilai $F_{\text {hitung }} 75,644>F_{\text {tabel }} 2,87$ dengan nilai signifikan variabel Ekonomi $\left(\mathrm{X}_{1}\right)$, variabel Efisiensi $\left(\mathrm{X}_{2}\right)$, dan variabel Efektivitas $\left(\mathrm{X}_{3}\right)$ terhadap Kualitas Laporan Keuangan Daerah $(\mathrm{Y})$ adalah 0,000 $<0,05$ sehingga dapat disimpulkan H4 diterima, yang berarti Sistem Pengendalian Keuangan Daerah dengan Ekonomi $\left(\mathrm{X}_{1}\right)$, Efisiensi $\left(\mathrm{X}_{2}\right)$, dan Efektivitas $\left(\mathrm{X}_{3}\right)$ berpengaruh positif signifikan secara simultan terhadap Kualitas Laporan Keuangan Daerah (Y).

\section{Hasil Uji Koefisien Korelasi}

Koefisien korelasi bertujuan untuk menguji apakah dua varibel mempunyai hubungan yang kuat atau tidak. Berikut hasil uji koefisien korelasi :

\section{Tabel 4}

Hasil Uji Koefisien Korelasi Model Summary ${ }^{b}$

\begin{tabular}{|l|c|r|r|r|}
\hline Model & $\mathrm{R}$ & $\begin{array}{c}\mathrm{R} \\
\text { Square }\end{array}$ & $\begin{array}{c}\text { Adjusted R } \\
\text { Square }\end{array}$ & $\begin{array}{r}\text { Std. Error of } \\
\text { the Estimate }\end{array}$ \\
\hline 1 &, $929^{\mathrm{a}}$ &, 863 &, 852 & 1,23880 \\
\hline
\end{tabular}

a. Predictors: (Constant), X3, X2, X1

b.Dependent Variable: Y

Sumber: data primer diolah, 2019
Berdasarkan hasil penelitian diatas, $\mathrm{R}=0,929$, apabila dilihat hubungan antar variabel, maka dapat disimpulkan bahwa Sistem Pengendalian Keuangan dengan Ekonomi (X1), Sistem Pengendalian Keuangan Daerah dengan Efisiensi (X2), dan Sistem Pengendalian Keuangan Daerah dengan Efektivitas (X3) terdapat korelasi yang sangat kuat terhadap Kualitas Laporan Keuangan Daerah (Y).

\section{Hasil Uji Koefisien Determinasi $\left(\mathbf{R}^{2}\right)$}

$$
\text { Menurut Siregar (2013:252), }
$$

koefisien determinasi adalah angka yang menyatakan atau digunakan untuk mengetahui konstribusi atau sumbangan yang diberikan oleh sebuah atau lebih variabel bebas terhadap variabel terikat. Jika $\mathrm{R}^{2}$ mendekati 1 artinya variabel independen memberikan hampir seluruh informasi yang dibutuhkan dalam memprediksi variabel dependen. Semakin tinggi nilai Adjusted- $\mathrm{R}^{2}$ maka semakin tinggi variabel independen dapat menjelaskan variasi variabel (Ghozali, 2005:87). Untuk menguji koefisien determinasi digunakan aplikasi SPSS seperti tabel berikut ini :

\section{Tabel 5}

Hasil Uji Koefisien Determinasi $\left(\mathbf{R}^{2}\right)$

Model Summary ${ }^{b}$

\begin{tabular}{|l|c|r|r|c|}
\hline Model & $\mathrm{R}$ & $\begin{array}{c}\mathrm{R} \\
\text { Square }\end{array}$ & $\begin{array}{c}\text { Adjusted } \mathrm{R} \\
\text { Square }\end{array}$ & $\begin{array}{c}\text { Std. Error of the } \\
\text { Estimate }\end{array}$ \\
\hline 1 &, $929^{\mathrm{a}}$ &, 863 &, 852 & 1,23880 \\
\hline
\end{tabular}

a. Predictors: (Constant), X3, X2, X1

b. Dependent Variable: Y

Sumber: data primer diolah, 2019

Berdasarkan tabel diatas, kita ketahui bahwa nilai koefisien determinasi $\left(\mathrm{R}^{2}\right)$ sebesar 0,863 (nilai ini diperoleh dari $\mathrm{R}^{2}$, yaitu $0,929 \times 0,929=0,863$ ) hasil tersebut kemudian dikali $100 \%$ menjadi $86,3 \%$. Dan nilai Adjusted $\mathrm{R}^{2}$ sebesar 0,852 hal ini berarti bahwa Sistem Pengendalian Keuangan dengan Ekonomi, Efisiensi, dan Efektivitas memberikan kontribusi atau sumbangan terhadap Kualitas Laporan Keuangan Daerah 
sebesar $85,2 \%$ sedangkan $14,8 \%$ merupakan variabel yang tidak diteliti.

\subsection{Pembahasan}

1. Pengaruh Sistem Pengendalian Keuangan Daerah dengan Ekonomi Terhadap Kualitas Laporan Keuangan Daerah

Hasil penelitian ini sejalan dengan penelitian Mahmud (2013) tentang pengaruh value For money terhadap akuntabilitas publik pada DPPKAD Kabupaten Gorontalo, yang menunjukkan bahwa value for money berpengaruh positif terhadap akuntabilitas publik di Kabupaten Gorontalo. Seterusnya hasil penelitian Novtania Mokoginta (2017) tentang pengaruh sistem pengendalian intren dan sistem akuntansi keuangan daerah terhadap kualitas laporan keuangan pemerintah, yang menunjukkan bahwa sistem akuntansi keuangan daerah terhadap kualitas laporan keuangan pemerintah berpengaruh secara positif.

\section{Pengaruh Sistem Pengendalian \\ Keuangan Daerah dengan Efisiensi Terhadap Kualitas Laporan \\ Keuangan Daerah}

Hasil penelitian ini sejalan dengan penelitian Arif Ardi Kusumah (2012) tentang pengaruh penerapan standar akuntansi pemerintah terhadap kualitas laporan keuangan, yang menunjukkan penerapan standar akuntansi pemerintahan berpengaruh signifikan terhadapan kualitas laporan keuangan. Seterusnya, hasil penelitian Nazril (2013) tentang value for Money terhadap pengelolaan kinerja keuangan, menunjukkan bahwa telah memenuhi prinsip metode value for money yang berpengaruh baik terhadap pengelolaan kinerja keuangan.

\section{Pengaruh Sistem Pengendalian \\ Keuangan Daerah dengan Efektifitas \\ Terhadap Kualitas Laporan \\ Keuangan Keuangan Daerah}

Hasil penelitian ini sejalan dengan penelitian Debi Putri Pertiwi (2015) tentang pengaruh akuntabilitas, transparansi, dan pengawasan terhadap pengelolaan anggaran berkonsep value for money pada Instansi Pemerintahan, yang menunjukkan bahwa akuntabilitas, transparansi, dan pengawan berpengaruh secara positif dan signifikan terhadap pengelolaan anggaran berkonsep value for money pada Instansi Pemerintah. Seterusnya hasil penelitian Novtania Mokoginta (2017) tentang pengaruh sistem pengendalian intren dan sistem akuntansi keuangan daerah terhadap kualitas laporan keuangan pemerintah, yang menunjukkan bahwa sistem akuntansi keuangan daerah terhadap kualitas laporan keuangan pemerintah berpengaruh positif.

\section{Pengaruh Sistem Pengendalian Keuangan Daerah dengan Ekonomi, Efisiensi, dan Efektivitas Terhadap Kualitas Laporan Keuangan Daerah}

Hasil penelitian ini sejalan dengan penelitian Mahmud (2013) tentang pengaruh value For money terhadap akuntabilitas publik pada DPPKAD Kabupaten Gorontalo, yang menunjukkan bahwa value for money berpengaruh positif terhadap akuntabilitas publik di kabupaten Gorontalo. Seterusnya hasil penelitian Novtania Mokoginta (2017) tentang pengaruh sistem pengendalian intren dan sistem akuntansi keuangan daerah terhadap kualitas laporan keuangan pemerintah, yang menunjukkan bahwa sistem akuntansi keuangan daerah terhadap kualitas laporan keuangan pemerintah berpengaruh secara positif. Dan penelitian R. Nelly Nur Apandi dan Adrianus Fajar (2010) tentang pengaruh sistem akuntansi keuangan daerah terhadap kualitas laporan keuangan pemerintah Kabupaten Bandung, yang menyatakan bahwa sistem akuntansi keuangan daerah memberikan pengaruh positif terhadap kualitas laporan keuangan pemerintah Kabupaten Bandung. 


\section{KESIMPULAN}

Berdasarkan hasil pembahasan dan uji hipotesis yang telah diuraikan pada pembahasan sebelumnya, maka dari pembahasan tersebut dapat ditarik suatu kesimpulan, yaitu sebagai berikut :

1. Sistem Pengendalian Keuangan Daerah dengan Ekonomi berpengaruh positif signifikan terhadap Kualitas Laporan Keuangan Daerah pada BPKAD Kota Bengkulu.

2. Sistem Pengendalian Keuangan Daerah dengan Efisiensi berpengaruh positif signifikan terhadap Kualitas Laporan Keuanga Daerah pada BPKAD Kota Bengkulu.

3. Sistem Pengendalian Keuangan Daerah dengan Efektvitas berpengaruh positif signifikan terhadap Kualitas Laporan Keuangan Daerah pada BPKAD Kota Bengkulu.

4. Sistem Pengendalian Keuangan Daerah dengan Ekonomi, Efisiensi, dan Efektivitas berpengaruh positif signifikan secara simultan terhadap Kualitas Laporan Keuangan Daerah pada BPKAD Kota Bengkulu.

5. Nilai Adjusted $R^{2}$ sebesar 0,852 hal ini berarti bahwa Sistem Pengendalian Keuangan dengan Ekonomi, Efisiensi, dan Efektivitas memberikan kontribusi atau sumbangan terhadap Kualitas Laporan Keuangan Daerah sebesar $85,2 \%$ sedangkan $14,8 \%$ merupakan variabel yang tidak diteliti.

\section{SARAN}

Berdasarkan hasil penelitian yang telah dilakukan, penulis dapat mengajukan saran sebagai berikut :

1. Bagi akademisi dan peneliti selanjutnya yang tertarik untuk melakukan penelitian sejenis, hendaknya menambah variabel penelitian dan populasi serta sampel yang digunakan seluruh SKPD yang berada di BPKAD Kota Bengkulu.
2. Bagi Pemerintah Daerah, khususnya di BPKAD Kota Bengkulu perlu lebih mengadakan pelatihan tentang Sistem Akuntansi Keuangan Daerah kepada seluruh pegawai untuk membentuk sebuah pemahaman yang lebih kepada para pegawai sehingga bisa memberikan hasil yang maksimal tugas pokok, dan fungsi masing-masing bagian dalam menyusun laporan keuangan.

3. Berdasarkan hasil penelitian yang menunjukkan bahwa Sistem Pengendalian Keuangan Daerah dengan Ekonomi, Efisiensi, dan Efektivitas berpengaruh positif signifikan terhadap Kualitas Laporan Keuangan Daerah, terlepas dari hal tersebut masih terdapat beberapa hal yang harus dibenahi seperti sumber daya manusianya agar hasil audit dari BPK pada tahun 2018 dapat dipertahankan sehingga laporan keuangan yang dihasilkan terus mendapatkan pendapat Wajar Tanpa Pengecualian.

\section{DAFTAR PUSTAKA}

[1] Halim, Abdul. 2007. Akuntansi Sektor Publik: Akuntansi Keuangan Daerah. Jakarta: Salemba Empat.

[2] Halim. 2007. Akuntansi dan Pengendalian Keuangan Daerah. Yogyakarta: UPP STIM YKPW.

[3] Harahap, Sofyan Syafri. 2008. Teori Akuntansi. Jakarta: PT RajaGrafindo Persada Agung, Kurniawan. 2005. Transformasi Pelayanan Publik. Yogyakarta: Pembaharuan

[4] Mardiasmo. 2002. Akuntansi Sektor Publik. Yogyakarta: ANDI.

[5] Mardiasmo. 2009. Akuntansi Sektor Publik. Yogyakarta: ANDI. 
[6] Masnun. 2018. Good Governance dan Kualitas Laporan Keuangan Pemerintah: Suatu Kajian di Pemerintah Daerah Provinsi Jambi. Jurnal of Economics and Business Vol. 2 No. 1. Universitas Batanghari

[7] Mulyadi. 2013. Auditing. Jakarta: Penerbit Salemba Empat.

[8] Peraturan Menteri Dalam Negeri Republik Indonesia Nomor 64 Tahun 2013 Tentang Penerapan Standar Akuntansi Pemerintahan Berbasis Akrual Pada Pemerintah Daerah.

[9] Peraturan Pemerintah Republik Indonesia Nomor 58 Pasal 1 Tahun 2005 Tentang Pengelolaan Keuangan Daerah.

[10] Peraturan Pemerintah Republik Indonesia Nomor 71 Tahun 2010 Tentang Standar Akuntansi Pemerintahan.

[11] Pernyataan Standar Akuntansi Pemerintah Nomor 01 Tahun 2010 tentang Penyajian Laporan Keuangan.

[12] Sedarmayanti. 2004. Good Governance: Pemerintahan yang Baik. Bandung: cv. Mandar Maju.

[13] Shella Zahar. 2017. Pengaruh Good Government Governance Terhadap Kualitas Laporan Keuangan Pemerintah Daerah (Studi Kasus Pada Bagian Staf Tata Usaha, Staf Pencatatan Asset dan Pembukuan Laporan Keuangan di Dinas Pendapatan Pengelolaan Keuangan dan Aset Daerah di Kabupaten Bandung Barat. Universitas Widyatama

[14] Siregar, Syofian. 2013. Metode
Penelitian Kuantitatif. Jakarta: Penerbit Kencana.

[15] Sugiyono. 2013. Metode Penelitian Bisnis. Bandung: Penerbit Alfabeta.

[16] Suryabrata, Sumadi. 2010. Metodologi Penelitian. Jakarta: Rajawali Pers.

[17]http://etheses.uinmalang.ac.id/2261/7/10 520035_Bab_3.pdf

[18] http://govmedikzmedikz.blogspot.com/2011/02/sistempengendalian-keuangan daerah.html

[19] www.academia.edu 